\title{
MEDIA REPORTAGE OF SEXUAL HARASSMENT: THE (IN)CREDIBLE COMPLAINANT**
}

\author{
Keziah Judd ${ }^{+}$and Patricia Easteal ${ }^{\#}$
}

\section{INTRODUCTION: THE MASS MEDIA AND THE COURT OF PUBLIC OPINION}

Studies of court and conciliation decisions about credible complainants and legitimate sexual harassment. In determining what is reasonable and indeed in assessing whether behavior was sexual and unwelcome and resulted in humiliation, it is often the complainant's identity, history and behaviour that are scrutinised and evaluated by conciliators and judicial officers. ${ }^{1}$ Youth can enhance credibility if the alleged harasser is older. Also, credible victims fight back, report immediately, are consistent in their evidence, are able to particularise and testify either in a non- aggressive and not too 'smart' manner or make an argumentative presentation coupled with confidence. ${ }^{2}$ Judicial commentary about the complainant's relationships, dress and attitudes to sexuality is a chilling echo of Catharine MacKinnon's 1979 observation that sexual harassment was often dismissed as 'trivial, isolated, and 'personal,' or as universal 'natural' or 'biological' behaviours..."”

These findings also confirm the feminist perspective that law must be looked at within the broader cultural context - in this instance in the broader context of beliefs about sexual harm. Those beliefs and the broader context

* This article appears as Chapter 4 in P Easteal (ed) Justice Connections (Cambridge Scholars Publishing 2013). The authors and publisher have given their permission to reprint it here.

${ }^{+} \mathrm{PhD}$ candidate with the University of Canberra, Australia

\# Professor, Faculty of Business, Government \& Law, School of Law, University of Canberra, Australia.

1 See Deb Tyler and Patricia Easteal, 'Sexual Harassment in the Tribunals: The Credibility Gap' (1998) 23 (5) The Alternative Law Journal 211; Patricia Easteal and Keziah Judd, 'She Said, He Said' Credibility and Outcome in Sexual Harassment' (2008) 31(5) Women's Studies International Forum 336; Patricia Easteal and Skye Saunders, 'The (Un)Successful Rural Workplace Sexual Harassment Complainant.' (Justice Connections Symposium, Canberra, June 2011).

${ }^{2}$ Ibid.

3 Catharine MacKinnon, Sexual Harassment of Working Women: A Case of Sex Discrimination (Yale University Press 1979) 1. 


\section{MEDIA REPORTAGE OF SEXUAL HARASSMENT}

are both reflected by and contributed to by the media. The media has been described as a shaper of attitudes through its use of narrative techniques:

"Stories create a causal chain: this happened because she did that, he responded by doing this. They identify notions of responsibility and blame; they make sense of the chaos of events 'out there', and in doing so steer the audience's response towards one view of the world rather than another."

In examining how female victims of sexual harassment are portrayed by the media, we must be aware that media reporting may be simplistic, misleading, and overly reliant on clichéd and 'archetypal characters' as 'ancient as they are inflammatory' - the seductress, the victimised man, and the man-hating woman. ${ }^{5}$

"The language of the media is limited: 'Feminists' are always 'ideologues'. 'Women in the workplace' invariably 'threaten the place of men'. 'Complaints' of sexual harassment are constantly 'on the rise'. The tone ranges from flattened to melodramatic, often, without that much in between."

Indeed it has been noted that feminism will always be working 'against the grain' when engaging with the media:

"The forms of feminist theory and practice that most challenge the liberal status quo are the most likely to be misunderstood and/or mistreated by the media because of the media's own reliance on a liberal paradigm. This presents a significant challenge for those feminists who attempt to work with or within the commercial media." ${ }^{7}$

\footnotetext{
${ }^{4}$ John Street, Mass Media, Politics and Democracy (Palgrave 2001) 4.

5 Jenna Mead (1997) (ed) 'Introduction - Tell it Like it Is,' Bodyjamming - Sexual Harassment, Feminism and Public Life Sydney: Allen and Unwin, at 6.

6 Ibid 6. Mead's term 'melodramatic' refers to classic tabloid journalism, with screaming simplistic headlines, highly emotive language, and a focus on scandal and gossip. While Mead herself does not define 'flattened,' we understand the term to refer to media commentary located beyond the front page, offering detailed but dry analysis to those readers who bother to dig for it.

7 Donna Young, 'Introduction' in Martha A Fineman, Martha T McCluskey, Feminism, Media and the Law (Oxford University Press 1997) 7.
} 
Much of the critical analysis of the media focuses on the idea of propaganda, with the media responsible for providing messages to subdue the populace, even in 'enlightened' liberal democracies.

"The mass media serve as a system for communicating messages and symbols to the general populace. It is their function to amuse, entertain, and inform, and to inculcate individuals with the values, beliefs, and codes of behaviour that will integrate them into the institutional structures of the larger society." ${ }^{8}$

The media constructs a version of 'reality' that favours those in power. Continuing in this vein, the media's use of clichéd characters can be seen as a shorthand method of reinforcing dominant social values about gender and the law. This use of media shorthand has been described as both political and problematic with television as 'myopically focused on the foreground of ordinary experience ${ }^{9}$ favouring the simple (and indeed the simplistic) at the expense of the complex:

It filters out 1) more abstract and conceptual structures or relationships, including systems (which are relationships that interact over time to produce particular results or to maintain a particular balance); 2) causality, particularly remote causal histories and destinies, evolutionary change, and uncertain or incomplete processes of change; 3) context, which is likewise relational and causative; and 4) ambiguity, i.e., uncertainty of meaning, and ambivalence, or uncertainty of value. ${ }^{10}$

This tendency for over-simplification, eschewing of context and reliance on broad-brush characterisation can be seen in media reporting of sexual harassment law, together with a love of drama and exaggeration. The latter would fall at the inflammatory, screaming headlines 'tabloid'-style coverage of the spectrum in contrast with the with the more thoughtful, detailed yet buried analysis associated with broadsheet articles beyond the front page. ${ }^{11}$

In 'Ripples from the First Stone,' Anya Poukchanski also identifies a blend of sensationalism and skepticism in the media when reporting sexual

\footnotetext{
8 Edward S Herman and Noam Chomsky, Manufacturing Consent - the Political Economy of the Mass Media (Vintage 1994) 1.

${ }^{9}$ Jeffrey Scheuer, The Sound Bite Society - How Television Helps the Right and Hurts the Left (Routledge, 2001) 121.

${ }^{10}$ Ibid 21-122.

${ }^{11}$ Mead (n 5).
} 


\section{MEDIA REPORTAGE OF SEXUAL HARASSMENT}

harassment cases. She comments, 'A scandal-happy media armed with the lurid resources of the internet means privacy for victims is almost impossible, and reputation is easily, and enduringly, marred. ${ }^{12}$ Poukchanski discusses the use of language to undermine the credibility of sexual harassment complainants, with particular attention to the term 'alleged':

"Journalists refer to the 'alleged victim', but it is the victim who is doing the alleging, against a person she claims to have committed a crime against her - the alleged assaulter. Referring to the "alleged" victim immediately casts the foundation of her claim into doubt; well she might be a victim, or she might be putting the whole thing on."13

\section{Identifying the Ties}

In the following paper we look at the style of writing in the reporting of a selection of Australian sexual harassment cases. We contrast broadsheets with tabloid, and the extent to which Mead's flattened/melodramatic dichotomy applies. We also particularly focus on how those who allege sexual harassment cases are characterised.

We analyse the reporting by a sample of Australian newspapers of five sexual harassment cases from mid 2010 through 2011. Using microfiche archives from the National Library of Australia and the online database Newsbank Newspapers Australia, we conducted an analysis of selected print media coverage of three New South Wales (NSW) based cases-Fraser-Kirk and David Jones, Bridgette Styles' complaint against Clayton Utz and CaroleAnn Britt's complaint against Patrick Stevedores and two Victorian mattersSusan Spiteri's complaint against IBM and Sallyanne Robinson's complaint against Rivers. For the NSW matters, articles appearing in three major Sydney newspapers - the broadsheet The Sydney Morning Herald, its weekend tabloid The Sun Herald and the populist tabloid The Daily Telegraph were identified. We used articles in daily broadsheet The Age, and the tabloids Herald Sun and Sunday Herald Sun for the cases to be heard in Melbourne Courts.

For each of the five, we looked at the 'splash' period, focusing our attention on the first month of reporting of the case. This period was chosen because at this time the case was 'fresh' in the minds of journalists and readers, and would have had the greatest impact. In the IBM case, we looked at two distinct 'splash' periods - when the case first hit the headlines it was

${ }^{12}$ Anya Poukchanski, 'Ripples from the First Stone' (2011) The Sydney Institute Quarterly Issue 39 10, 12.

${ }^{13}$ Ibid. 
announced in the media in April 2011, and when the claim was filed in the Federal Court in October 2011.

Having developed a pro forma template, we recorded variables such as how the media portrayed the parties, the behaviour complained of, the relationship between the complainant and alleged harasser, whether the complainant's response to harassment was discussed and whether the age of the complainant was mentioned. We also noted and report below relevant 'grabs' that are indicative of sensationalism and/or stereotyping and melodramatic versus flat reporting. After the textual analysis was complete, aside from looking at the aggregate findings, we compared the broadsheet to the tabloid coverage.

\section{Caveat}

The generalisability of our findings is limited both by the small sized sample and our focus on reportage in only four Australian newspapers. Any conclusions must be regarded as preliminary and not necessarily true for other print or visual media or for other types of cases.

\section{2. 'FACTS' OF THE FIVE CASES}

The facts of the David Jones case are well known to Australian readers. Junior publicist Kristy Fraser-Kirk made a complaint of sexual harassment against former CEO Mark McInnes. In her statement of claim, Ms Fraser-Kirk stated that Mr McInnes engaged in repeated unwelcome conduct of a sexual nature toward her, including telling her that a dessert was like a "fuck in the mouth", placing his hand under her clothing and touching her bra, trying to kiss her on the mouth and repeatedly asking her to accompany him to his home at Bondi. ${ }^{14}$ Ms Fraser-Kirk also stated that when she reported these incidents to her supervisor at David Jones, she was told to say "no, Mark" and her complaints were not addressed. ${ }^{15}$ some of the alleged harassment took place at work functions which were held away from the workplace or were text messages which were sent to the complainant whilst she was at home, if that matter had proceeded to a hearing, the test for vicarious liability may have failed.

In the Clayton Utz case, Bridgette Styles complained of harassing behaviour by her colleagues, and described the law firm as a "hostile place to

\footnotetext{
14 Fraser Kirk v David Jones \& Ors (2010) NSD 964/2010 Statement of Claim $<$ http://resources.news.com.au/files/2010/08/02/1225900/118204-aus-bus-file-djsstatement-pdf.pdf $>3$.

${ }^{15}$ Ibid 4.
} 
work", where managers failed to take action against a facebook group called "Clayton Utz Workplace Relations (Sydney) Whorebags."16 Ms Styles claimed that after her relationship with colleague Luis Izzo ended, she was harassed by other employees, who "posted a photo and montage of images of Mr Izzo with the caption 'I'm nice to look at' near her desk in the firm's workplace relations group." ${ }^{17}$ Ms Styles also complained of sexual comments being made to her by colleagues during work functions, a failure by her employer to investigate her complaint of sexual harassment and victimisation in the workplace following the making of her complaint. ${ }^{18}$

In the IBM matter, the complainant Susan Spiteri alleged harassing behaviour by a former senior manager, which included telling her to " get those boobies out' to get sales."19 Ms Spiteri's complaint also included allegations that this manager made sexual remarks in front of her during Christmas events, repeatedly placed his hand on her leg and up her dress at a work function, and engaged in bullying behaviour such as name-calling and phoning her late at night. ${ }^{20}$ A Herald Sun article on the case noted, "Despite complaining to four managers, no action was taken for 18 months, and only after the woman attempted suicide was the perpetrator forced to resign in mid2009."21 The article then quoted the complainant's legal representative Siobhan Keating, "IBM's inaction is impossible to understand." 22 In written judgment on an application for interlocutory relief, Jessup J commented:

"I should emphasise that the applicant does not allege in her Statement of Claim that any of those respondents directly engaged in any conduct which would be unlawful under the Sex Discrimination Act. Rather, the case against them is that they failed to act to prevent the particular perpetrator from engaging in the conduct which was said to be unlawful on his part." 23

16 Louise Hall, 'Claims of sexism as young lawyer takes on top firm' The Sydney Morning Herald, (Sydney 8 June 2011) 3.

17 Ibid.

18 Styles v Clayton Utz (No 3) [2011] NSWSC 1452 12-17, 21-22, 120 (MacCallum $\mathrm{J})$.

${ }^{19}$ Author not named, 'Woman sues IBM for bullying by boss' The Age, (Melbourne, 21 October 2011) 7.

${ }^{20}$ Marianne Betts, 'Woman sues IBM for \$1.1m - Sex pest legal fight' Herald Sun (Melbourne, 15 April 2011) 9.

${ }^{21}$ Ibid.

22 Ibid.

${ }^{23}$ Spiteri v IBM Australia Ltd [2011] FCA 13184 (Jessup J). 
In the Rivers case, former executive Sallyanne Robinson made a civil claim against the company for harassment by its owner and sole director ${ }^{24}$, Philip Goodman. Her statement of claim was reported as including complaints of unwanted sexual advances, unwanted touching of her breasts and bottom, being asked to model the company's underwear range, and being addressed as "honey bun" and "bunny". 25

In the Patrick Stevedores matter, dock worker Carole-Ann Britt complained of a hostile work environment, in which she was surrounded by "posters of naked women and piles of pornographic magazines and regularly asked about her sex life". ${ }^{26}$ Alleged behaviours included the display of pornography on an overhead projector during a meeting. ${ }^{27}$ Ms Britt said that she made a complaint to the maritime union after a male colleague drove her to a remote location on the port, touched her between the legs and encouraged her to have sex with him. ${ }^{28}$

\section{FANFARE V MUTED COVERAGE}

While the David Jones (DJs) case appeared in the media with considerable fanfare, coverage of the other cases was considerably more muted. During August 2010, the DJs matter received front page coverage in The Sydney Morning Herald and The Daily Telegraph on five separate occasions. ${ }^{29}$ For the other four cases in our sample, only two articles made the front page. ${ }^{30}$

The sheer volume of the coverage of the David Jones case was extraordinary. During its first month, the David Jones case was the subject of

${ }^{24}$ Hamish Heard, 'Assault payout' Sunday Herald Sun (Melbourne, 13 November 2011) 21 .

${ }_{25}$ Cameron Houston, 'Rivers tycoon on sex assault charge' The Sunday Age (Melbourne, 4 December 2011) 1.

${ }^{26}$ Tim Barlass, 'Sexist port workers in the dock - Stevedore 'surrounded by porn' Blames sexual assault on toxic atmosphere' The Sun Herald (Sydney, 11 December 2011) 3 .

${ }^{27}$ Ibid.

${ }^{28}$ Ibid.

${ }^{29}$ Belinda Kontominas and Simon Mann, 'Are you being sued? Sordid details of $\$ 37$ million DJs sex claim' The Sydney Morning Herald (Sydney, 3 August 2010) 1, 6; Andrew Hornery, 'From lawsuit to swimsuit, DJs dodges 'M' word' The Sydney Morning Herald (Sydney, 4 August 2010) 1-2; Janet Fife-Yeomans, 'Inside Australia's biggest harassment case $\$ 37 \mathrm{~m}$ SEX SUIT' The Daily Telegraph (Sydney, 3 August 2010) 1-3; Nick Tabakoff, 'DJs to set up bully hotline' The Daily Telegraph (Sydney, 7 August 2010) 1-2 and the front page teaser headline 'New DJs revelation: $\$ 37 \mathrm{~m}$ battle turns nasty, page 3' The Daily Telegraph (Sydney, 8 August 2010) 1.

${ }^{30}$ Houston (n 25) 1. 
26 articles in The Sydney Morning Herald, and 24 articles in The Daily Telegraph. However, the other cases in our sample have not attracted this level of coverage. The Clayton Utz case was the subject of two articles in The Sydney Morning Herald, and two articles in The Daily Telegraph. The IBM case appeared twice in The Age, and two times in the Herald Sun. The Rivers case was the subject of one article in the Age, one in the Herald Sun and one in the Sunday Herald Sun. The Patrick Stevedores case, which arguably made the most serious allegations in our sample, was reported in a single article in only one newspaper; The Sun Herald.

\section{MELODRAMATIC V FLAT (TABLOID V BROADSHEET)}

We anticipated that there would be differences between the tabloid and broadsheet coverage. However, the cases in our sample showed that sometimes the line is not so clear. For example, much of The Sydney Morning Herald coverage of the David Jones case had a 'scandal and gossip' element, with much of the reporting on the case done by the Herald gossip columnist Andrew Hornery for his "Private Sydney" column. In contrast, once the melodramatic "sex fight" headlines were stripped away, the Herald Sun provided some surprisingly thoughtful commentary on the Rivers case.

We found that some of the coverage of the Fraser-Kirk case was nuanced but a flattened/melodramatic dichotomy was present in much of the media reporting, and ancient sexist stereotypes have continued to appear.

As legal practitioners representing Fraser-Kirk, McInnes and David Jones competed for media attention and sympathetic coverage, much of the coverage focused upon the size of the claim and the credibility of the complainant. In some of the more prominently placed articles, these newspapers provided a platform for the players to make their respective announcements, and argue their cases. Both the broadsheet and the tabloid newspapers highlighted the 'scandalous gossip' aspects of the case, with the publication of provocative yet irrelevant sound bites from fashion designer Alannah Hill in the 'Private Sydney' column, and speculation from The Telegraph about Sydney private investigator Frank Monte shadowing the complainant. In many articles, journalists provided their own critical analysis of the legal and social implications of the case, or its impact on the economic position of the David Jones brand. The most 'flattened', yet detailed and legally accurate articles on David Jones were buried in the Business Day liftout section of the Herald, which is separate from the main newspaper. The Telegraph coverage of the David Jones case fell predictably into the 'melodramatic' camp, with a focus on the more colourful aspects of the case.

A critical difference between the melodramatic and flattened commentary in both newspapers was the treatment of the tortious component of the claim. 
In the melodramatic camp, commentators who chose to position Fraser-Kirk as the gold-digger generally did not concern themselves with the difference between compensatory and punitive damages. Miranda Devine's column for the Herald presents a typical example:

"Woman (sic) who are raped don't get that kind of money as victims compensation - they're lucky if they receive $\$ 100,000$. A woman who was raped by a navy colleague at HMAS Cairns was awarded less than $\$ 500,000$ in 2007 in a sexual harassment lawsuit. A David Jones employee who sustained a serious brain injury at work would get less than $\$ 300,000$ in compensation under WorkCover. So why does McInnes's conduct qualify for such a grand cash grab?"31

Although written with a fine rhetorical flourish, this statement fails to grasp the differences between an award of compensatory damages to return complainants to their original positions prior to the wrong suffered, compensation awarded under statutory no-fault schemes, and punitive damages to punish tortfeasors for their conduct. Such a basic error rendered the article very misleading in its analysis of legal issues.

A handful of commentators in the DJs articles did take pains to clarify the punitive nature of the claim. For example, in The Sydney Morning Herald, Kate Lahey commented:

"The figure is unusual for two reasons. Its sheer size is light years away from usual payouts in such cases and the nature of the damages sought is equally rare. It is designed as punishment, beyond general compensation damages for actions so egregious they warrant the extra penalty - unheard of in discrimination cases in Australia., 32

However, such analysis was the exception rather than the rule. Only one of the Telegraph articles referred to the purpose of punitive damages, "If she wins, it would be the first time any Australian court has awarded punitive damages to punish an employer in a sexual harassment case." ${ }^{\text {33 }}$

The flattened/melodramatic dichotomy was also seen in The Daily Telegraph reporting of the Clayton Utz case. At first, The Daily Telegraph

\footnotetext{
${ }^{31}$ Miranda Devine, 'Nobody died, so why is she demanding a king's ransom?' The Sydney Morning Herald (Sydney, 5 August 2010) 15.

${ }^{32}$ Kate Lahey, "No" gets no firmer than a $\$ 37$ million lawsuit' The Sydney Morning Herald (Sydney, 4 August 2010) BusinessDay 1.

33 Janet Fife-Yeomans, ' $\$ 37 \mathrm{~m}$ sex suit: Inside Australia's biggest harassment case' The Daily Telegraph (Sydney, 3 August 2010) 2.
} 
appeared to have little interest in Styles' case, with its first report of the case being confined to a tiny 'news in brief' column on page $13,{ }^{34}$ which was a classic example of 'flattened' coverage. The brief article noted, "A former Clayton Utz lawyer who is suing the top-tier firm for sexual harassment and defamation said she never made a formal complaint because she feared for her job." ${ }^{35}$ Melodramatic reportage began when the newspaper launched a blistering attack on the complainant, with a more sympathetic focus on her alleged harasser. ${ }^{36}$ The melodrama escalated with an article on the victimised 'man in the middle' of the case, and an unflattering portrait of the complainant as a scorned harridan: "Mr Izzo's brief fling with fellow lawyer Bridgette Styles triggered a volley of legal claims from his scorned lover." 37

The Rivers case attracted the melodramatic headline "TYCOON SEX FIGHT" with its front page coverage in the Herald Sun, ${ }^{38}$ but the article itself struck a good balance between the flattened and the melodramatic. While aspects of the complaint were spelt out in detail, the article appeared to take pains to describe both sides of the case without the use of further inflammatory language like 'sex fight', and ended with the almost bland statement, "The matter is expected to be heard next year.",39

The Herald Sun took a similarly dramatic approach in its headlines for the IBM case, with the sensationalist titles: "Woman sues IBM for $\$ 1.1 \mathrm{~m}-$ Sex pest legal fight" and "Woman sues IBM for $\$ 1.1 \mathrm{~m}$ - Worker allegedly told to "get boobies out"" 40 These headlines demonstrated the preoccupation with money and melodrama that we found in the David Jones coverage. "Sex pest legal fight" opened with a focus on the most dramatic aspects of the case: the size of the claim, and the "salaciousness" of the harassment:

"A FORMER female executive is suing a major Melbourne company for $\$ 1.1$ million after it allegedly failed to act on her repeated complaints of serious sexual harassment ....If she is awarded $\$ 1.1$ million it could be the biggest sexual harassment payout in Australian history. Maurice Blackburn lawyer Siobhan Keating said the allegations included that a male colleague had rubbed himself against

\footnotetext{
34 'Lawyer's job fears' The Daily Telegraph (Sydney, 8 June 2010) 13.

${ }^{35}$ Ibid.

${ }^{36}$ Vanda Carson, 'Man in the middle of $\$ 200 \mathrm{~K}$ claim - Law firm's sexual harassment case' The Daily Telegraph (Sydney, 4 July 2010) 17.

${ }^{37}$ Ibid.

${ }^{38}$ Shelly Hadfield, 'Millionaire denies woman's harassment court claim - TYCOON SEX FIGHT’ Herald Sun (Melbourne, 5 November 2010) 1, 4.

${ }^{39}$ Ibid.

${ }^{40}$ Betts (n 20); Ruth Lamperd, "Woman sues IBM for $\$ 1.1 \mathrm{~m}$ - worker allegedly told to 'get boobies out"” Herald Sun (Melbourne, 20 October 2010) 13.
} 
the woman and that he made comments such as, 'if you get your breasts out, you will get more sales.",41

In contrast, the Age reported on the case in its 'business' section, and adopted a more subdued tone, with less of a focus on describing the behaviour in gory detail, and a placing of the case in the context of recent legal history:

“A SEXUAL harassment claim for $\$ 1.1$ million brought by a top IBM saleswoman shows the failure of companies to implement their own policies properly, the woman's lawyer says. The woman, whose lawyers will not name her because of her "delicate mental state", ${ }^{2}$ is likely to lodge a Federal Court claim against IBM next week. She claims she endured almost two years of sexual harassment, discrimination and bullying at the hands of a male senior manager. Maurice Blackburn special counsel Siobhan Keating said the case, together with the lawsuit against against former David Jones chief executive Mark McInnes brought last year by publicist Kirsty FraserKirk, showed 'the gap in how far corporate Australia has come with sexual harassment.'

While the size of the claim was of interest and the article covered the same information as its Herald Sun counterpart, the selection of quotes from the complainant's solicitor demonstrated an interest in the legal, rather than the 'sexual', aspects of the case.

\section{CREDIBILITY AND CHARACTER}

In their coverage of Fraser-Kirk, the Herald and Telegraph used similar criteria as the Courts in assessing her credibility. In the 'flattened' and 'melodramatic' articles just described, her identity, history and behaviour were scrutinised and evaluated. At first glance, Fraser-Kirk appeared to fit the stereotype of the credible complainant in the Court discussed above. She was almost twenty years younger than her alleged harasser, and in a clearly

\footnotetext{
${ }^{41}$ Ibid Betts

${ }^{42}$ No suppression orders of the complainant's name appear to be in place at this time. The complainant's full name has been used in judgments on the Federal Court website, and can be seen in the online court file of the case: Susan Spiteri v IBM Australia \& Ors, Federal Court of Australia, Victorian Registry VID1134/2011 https://www.comcourts.gov.au/file/Federal/P/VID1134/2011/actions

${ }^{43}$ Ben Butler, "IBM saleswoman in $\$ 1.1 \mathrm{~m}$ sexual harassment claim" The Age (Melbourne, 11 April 2011) 3.
} 


\section{MEDIA REPORTAGE OF SEXUAL HARASSMENT}

subordinate position in the workplace hierarchy. She made a prompt, very vocal complaint of harassment. Her statement of claim documented the allegations of harassment with precision. This was certainly the picture of Fraser-Kirk that her public relations and legal team attempted to paint, when she addressed the media on 2 August 2010. Looking scared but brave, accompanied by her parents and boyfriend, she said, "I'm a young woman standing here today simply because I said it wasn't OK, because I said that this should never happen to anyone". ${ }^{44}$

Many of the articles did refer to Fraser-Kirk's relative youth. Thirteen Herald articles and eight Telegraph articles reported her age. In contrast, there appeared to be less interest in the age of McInnes, which was only reported in three Herald articles and one Telegraph article.

This interest in the age of the complainant was also apparent in the other cases in our sample. While Styles' age was not specifically mentioned in the media coverage, the two Sydney Morning Herald articles made a point of characterising her as a "young lawyer ${ }^{45}$ when reporting on her complaint against Clayton Utz.

As with Fraser-Kirk, there was a high level of scrutiny of her behaviour in some of the coverage. For instance, in The Telegraph:

"When she told Mr Izzo how she felt about the photos at an after-work drinks session at Sydney's Ryan's Bar, Mr Izzo reported to the law firm management that he believed she was using the threat of a harassment claim as a bargaining chip with management. Just weeks after she joined the prestigious firm, Mr Izzo alleges Ms Styles accused him of 'spading other girls', 'looking for his next victim' and 'being such a slut.",46

In its choice of quotations, the journalist appears to make connections between Ms Styles' workplace rotations as a graduate solicitor and her complaint of sexual harassment, with some implications for her credibility as a complainant:

"They dated for three weeks before she joined the firm, but the couple agreed to end their relationship once Ms Styles began work. She said shortly after she began a rotation with the company's workplace

\footnotetext{
${ }^{44}$ Kontominas and Mann (n 29) 1.

${ }^{45}$ Louise Hall, 'Claims of sexism as young lawyer takes on top firm' The Sydney Morning Herald (Sydney, 8 June 2011) 3 and Emma McDonald, 'Life in the firm still no picnic for women' The Sydney Morning Herald (Sydney, 9 June 2011) 15.

${ }^{46}$ Carson (n 36).
} 
relations department - which advises large companies and government on claims of unfair treatment by employees - she felt harassed. ${ }^{, 47}$

The last line of the article can be read as a parting shot at the complainant, her credibility and her work performance, "Ms Styles was sacked in December 2008. She is seeking at least $\$ 200,000$ in damages."

Indeed, analysis of reportage on these five cases shows that language may be used to paint a picture of incredibility. In a Herald Sun article on the IBM case, the reporter suggested that the complainant may have been the archetypal incredible woman through repeated use of the word 'allegedly'. The complainant's legal representative is also mentioned as labelling her client's complaint as an allegation:

"Maurice Blackburn lawyer Siobhan Keating said the allegations included that a male colleague had rubbed himself against the woman and that he made comments such as, 'if you get your breasts out, you will get more sales." ${ }^{49}$

The article went on, "He had also allegedly made sexual remarks in front of her during Christmas events, and had allegedly repeatedly placed his hand on her leg and up her dress several times at an evening function...He also allegedly bullied her..."

The Daily Telegraph gets the award for biggest turnaround in its Clayton Utz coverage. Its first article on the case was a miniscule 'news in brief' item called "Lawyer's job fears". Then a few weeks later, it was a profile on the 'man in the middle' of the allegations, and a blistering attack on the complainant's credibility.

Reportage on the Rivers matter showed that mental health issues could be a double-edged sword for complainant credibility, and presented competing pictures of a hysterical, incredible woman and an injured victim of 'real' sexual harassment. Coverage of the Rivers case focused on two attributes of the parties: the complainant, Robinson's mental health and the respondent Philip Goodman's wealth. An article in The Age included a description of the latter's lavish lifestyle:

"Goodman has made a fortune from a national chain of more than 150

Rivers stores. He owns two adjoining mansions in an exclusive

\footnotetext{
${ }^{47}$ Ibid.

48 Ibid.

${ }^{49}$ Betts (n 20).

${ }^{50}$ Ibid.
} 


\section{MEDIA REPORTAGE OF SEXUAL HARASSMENT}

Toorak court, where he keeps a fleet of prestige cars including a babyblue Bentley and a red Ferrari California."

Tabloid and broadsheet coverage alike devoted significant column space to the respondent, and defence attacks on the complainant's credibility. One Herald Sun article opened with a focus on the respondent and his wealth:

"A top retail tycoon has been accused of sexual harassment against a female worker, allegedly getting her to model underwear for him and spy on a business rival. Millionaire Philip Harry Goodman, 54, is the sole director of the Rivers Australia chain, which has 50 stores across Victoria." 52

The remainder of the article devoted equal space to the complainant and respondent's respective cases, noting that the complainant, "claims in court documents that Mr Goodman:

- PATTED her on the bottom and grabbed her breast

- REQUIRED her to model underwear for him in private, during which time she claims he placed his hands over and under her bra.

- TOLD her to pretend to be his wife or girlfriend during product sample purchases and called her 'honey bun'.

- OFFERED her gifts and insisted she call in sick so they could go to lunch.

- REQUIRED her to wear glasses fitted with cameras to covertly photograph products and displays of a competitor." ${ }^{, 53}$

Then the defence's case was outlined:

"In a defence document responding to Ms Robinson's claims, $\mathrm{Mr}$ Goodman and Rivers allege she has a history of bipolar behaviour, and that she suffered a range of ailments and conditions during her time with Rivers, including alcohol abuse -- a claim she denies. They said Ms Robinson at no time modelled underwear or was naked -- but that she insisted on trying on underwear samples in front of $\mathrm{Mr}$ Goodman. They claim it was part of her duties as accessories product developer, charged with building the women's underwear range, that she try on samples. Mr Goodman denied touching Ms Robinson's

${ }^{51}$ Cameron Houston (n 25).

${ }^{52}$ Hadfield (n 38).

${ }^{53}$ Ibid $1,4$. 
breasts or bottom. Rivers claims in the course of her job, he and Ms Robinson went to shops to assess clothes, and he would have told her that if she was approached by sales staff, she should adopt the role of being a couple. Rivers and Mr Goodman admitted getting her to covertly photograph a competitor's goods but said that was not victimisation., 54

These kind of attacks on the complainant's credibility, were also reported extensively by The Age:

"[The defence] claimed the Rivers employee did 'nudie runs after having drunk too much alcohol' and 'got so wasted on occasions at the end of a night out that she can't walk'. Max Legal lawyer Terry McHugh slammed the personal attacks on his client." 55

The complainant's mental health was also used by her own legal representatives in the media - albeit to present her sexual harassment claims as credible:

"Ms Robinson, now of Queensland, who claims she has suffered posttraumatic stress disorder, depression and panic attacks, declined to comment. Her lawyers say she is 'attempting to re-establish her career." $" 56$

The limited reportage of the Patrick Stevedore complaint is markedly dissimilar to the other four with no aspersions or hints of victim incredibility. The portrayal of Britt, who described her workplace as a toxic environment, was quite sympathetic and focused on the details of the sexual harassment:

"Carole-Ann Britt claims that she, as a handful of female workers among 450 men at Patrick's Port Botany docks, she was surrounded by posters of naked women and piles of pornographic magazines and regularly asked about her sex life... The matter came to a head when she alleges she was driven at night to a secluded part of the port behind freight containers where a male employee placed his hand between her legs and encouraged her to have sex with him., ${ }^{, 57}$

\footnotetext{
${ }^{54}$ Ibid 4.

${ }^{55}$ Houston (n 51).

${ }^{56}$ Hadfield (n 38).

${ }^{57}$ Barlass (n 26). As discussed above, this case only appeared in one newspaper story.
} 
The article quoted the complainant's legal representative's description of the matter as "the worst case of sexual harassment I have ever seen" 58 and a Patrick Stevedores spokesperson expressing disappointment over the failure of conciliation and the complainant's decision to speak to the media. ${ }^{59}$

\section{CONCLUSION}

A common feature of both media reporting and judgments is the focus upon the credibility of the complainant as opposed to the respondent. Discussion of the complainant's behaviour, response to harassment and mental health was a common feature of the newspaper coverage. While there was some discussion of the respondent's behaviour in the Rivers case, it was the complainant who held the most interest for journalists. Coverage of the IBM case and Rivers case placed considerable focus on the mental health of complainants.

In Court hearings, the credibility or character of the complainant appears to correlate with a finding in her favour. ${ }^{60}$ In contrast, the media's presentation of the woman did not seem to affect the outcome. For example, coverage tended to be more sympathetic to the complainant in the other four cases than towards Fraser-Kirk. She was depicted in many of the stories as avaricious. Yet her matter settled for a reputedly higher amount than in the other four.

The melodramatic nature of the coverage did not necessarily equate to a credible or incredible picture of the complainant in a sexual harassment case. Generally, the melodramatic reporting focused on the 'sexual' aspects of the complaint in lurid detail, and the complainant's response to harassment. This could include either a sympathetic portrayal of the complainant, as in the Patrick Stevedores coverage, or an unsympathetic portrayal, as seen in the Telegraph coverage of the Clayton Utz case.

Although the more 'flattened' commentary did not make the same judgments of complainant incredibility as the 'melodramatic' coverage, its 'buried' nature made it less accessible to all but the most interested readers. The more 'flattened' commentary also did not necessarily equate to a more credible presentation of the complainant, or a discussion of the complainant at all. The Telegraph 'news in brief' item on the Clayton Utz case amounted to a 'burying' of the story, and gave no impression of Ms Styles as a complainant, either credible or incredible. The more 'flattened' Sydney Morning Herald coverage in its Business Day liftout of the David Jones case did not make the

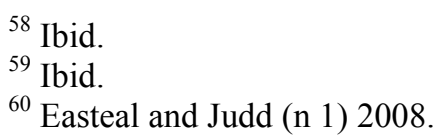


same credibility judgments as the Private Sydney columns in the main paper, but its more nuanced coverage was not placed in a prominent position.

It is somewhat disturbing then to see how the mass media plays an important role in the shaping of community attitudes, by using stories to present its own 'reality.' It is this 'reality' that gives the general community their information about sexual harassment and the law. The coverage was somewhat uneven in its focus, with some articles addressing relevant legal issues, and others showing a greater interest in using language to undermine the credibility of complainants. For instance, whilst it is important for the media to be careful in reporting of court cases and show an understanding of key concepts like damages, and to not describe matters in dispute as established facts, the journalist's use of the word 'allegedly' five times and 'allegations' twice in the 300 word article about the IBM case does seem excessive.

Further, the melodramatic coverage presented patchy legal information for readers, and a continuing influence of sexist stereotyping. Many of the articles included irrelevant information, such as suggestions that the complainant in the Rivers case engaged in 'nudie runs' when drunk, that presented a picture of an incredible complainant but did not have any bearing on her complaint of sexual harassment. Information of this kind can be challenged in a court of law before being admitted in evidence, but the complainant does not have this option if these statements are already in print.

Therefore, if the media indeed creates its own 'reality,' it presents a problematic picture of sexual harassment law for potential complainants and respondents, and leaves a somewhat misleading impression of their respective rights and responsibilities. In the ways described here, it would seem that the Australian tabloid and broadsheet print media, like their overseas counterparts, do indeed frequently rely on broad-brush characterization and evocative language, which may impact upon how sexual harassment complainants and perhaps sexual harassment itself, are regarded by the community. 